\title{
Extremely Elevated Total Mercury and Methylmercury in Forage Plants in a World Large-scale Abandoned Hg Mining Site: A Potential Risk of Exposure to Grazing Animals
}

\author{
Xiaoli Qian \\ Guizhou University \\ Chendong Yang \\ Guizhou University \\ Xiaohang Xu \\ Institute of Geochemistry, Chinese Academy of Sciences \\ Ming Ao \\ Guizhou University \\ Zhidong Xu \\ Institute of Geochemistry Chinese Academy of Sciences \\ Yonggui Wu \\ Guizhou University \\ Guangle Qiu ( $\nabla$ qiuguangle@vip.skleg.cn ) \\ Institute of Geochemistry Chinese Academy of Sciences https://orcid.org/0000-0002-1599-4795
}

\section{Research Article}

Keywords: Total mercury, Methylmercury, Potential exposure risk, Forage plants, Wastelands

Posted Date: February 9th, 2021

DOI: https://doi.org/10.21203/rs.3.rs-175400/v1

License: @ (i) This work is licensed under a Creative Commons Attribution 4.0 International License. Read Full License

Version of Record: A version of this preprint was published at Archives of Environmental Contamination and Toxicology on March 19th, 2021. See the published version at https://doi.org/10.1007/s00244-021-00826-2. 


\section{Abstract}

Ninety-five wild forage plants (belonging to 22 species of 18 families) and their corresponding rhizosphere soil samples were collected from wastelands of a world large-scale abandoned $\mathrm{Hg}$ mining region for total $\mathrm{Hg}(\mathrm{THg})$ and methylmercury $(\mathrm{MeHg})$ analysis. The forage plant communities on the wastelands were dominated by the Asteraceae, Crassulaceae and Polygonaceae families. The THg and MeHg concentrations in the forage plants varied widely and were in the range of 0.10 to $13 \mathrm{mg} / \mathrm{kg}$ and 0.19 to $23 \mu \mathrm{g} / \mathrm{kg}$, respectively. Shoots of Aster ageratoides showed the highest average THg concentration of $12 \pm 1.1 \mathrm{mg} / \mathrm{kg}$, while those of Aster subulatus had the highest average MeHg concentrations of $7.4 \pm 6.1 \mu \mathrm{g} / \mathrm{kg}$. Both the $\mathrm{THg}$ and MeHg concentrations in the aboveground plant parts exhibited positive correlations with the $\mathrm{THg}(\mathrm{r}=0.70, P<0.01)$ and $\mathrm{MeHg}(\mathrm{r}=0.68, P<0.01)$ concentrations in the roots but these were not correlated with the $\mathrm{THg}$ and $\mathrm{MeHg}$ concentrations in their rhizosphere soils. The species $A$. ageratoides, A. subulatus, and S. brachyotus showed strong accumulation of $\mathrm{Hg}$ and are of concern for herbivorous/omnivorous wildlife and feeding livestock. Taking the provisional tolerable weekly intake (PTWI) values for IHg recommended by the JECFA (2010) for human dietary exposure of $4 \mathrm{ng} / \mathrm{g}$ into account, grazing on $1.0 \mathrm{~kg}$ of forage (dry weight) by a $65 \mathrm{~kg}$ animal would mean that the daily intake of IHg was between 190-13200 $\mu \mathrm{g}$, which reaches 3-5 order of magnitude higher than the permitted limit, suggesting a potential risk of exposure.

\section{Introduction}

Mercury $(\mathrm{Hg})$ is a global pollutant and $\mathrm{Hg}$ exposure can increase the risk of cardiovascular disease and have neurological effects on humans, even at low concentrations (Driscoll et al., 2013; Peng et al., 2015). Mining and retorting of cinnabar ores are major sources of metal $\mathrm{Hg}$, which is also one of the major sources of anthropogenic $\mathrm{Hg}$ to the environment (Xu et al., 2019). The areas impacted by historic $\mathrm{Hg}$ mining continue to be threatened by the heavy $\mathrm{Hg}$ pollution caused by the abandoned mine-waste calcines (ignited residues). These are enriched with water-soluble secondary $\mathrm{Hg}$ compounds, such as meta cinnabar, polymorphic sulfide $\mathrm{Hg}$, sulphate $\mathrm{Hg}$, chloride $\mathrm{Hg}$, etc. Those large amounts of water-soluble $\mathrm{Hg}$ in effluent discharges from mine-waste calcines can be readily transformed into the more toxic methylmercury (MeHg) under suboxic conditions (Qiu et al., 2005; Lin et al., 2010). MeHg is considered the most harmful form of $\mathrm{Hg}$ due to its high lipophilicity (Agency for Toxic Substances and Disease Registry, 2013), so the transformation, bioaccumulation, and biomagnification of $\mathrm{MeHg}$ is of the greatest concern.

China has rich cinnabar deposits, and it ranks third in the world for its total reserves. Of these mines, the Wanshan Hg mine was once known as the "Mercury Capital", and it was the largest elemental Hg production center in China. Activities are exploiting this area in China date back to the Qin Dynasty (220 B.C.). These activities have resulted in severe environmental $\mathrm{Hg}$ contamination and generated significant quantities of wastelands. THg concentrations as high as 4,400 mg/kg have been found in mine-waste calcines of the Wanshan $\mathrm{Hg}$ mine, as high as $790 \mathrm{mg} / \mathrm{kg} \mathrm{Hg}$ in soils from paddies, and 10,000 ng/L Hg in surface water (Horvat et al., 2003; Qiu et al., 2005). The highest concentrations of $\mathrm{Hg}$ in the soils from the abandoned $\mathrm{Hg}$ mining region were approximately 2-3 orders of magnitude higher than the 'probable effect concentration' of $1.06 \mathrm{mg} / \mathrm{kg} \mathrm{Hg}$, above which harmful effects on organisms are likely to be observed (MacDonald et al., 2000; Conko et al., 2013), posing public concerns.

Many studies have shown that mine-waste calcines sites are favorable for $\mathrm{Hg}$ methylation in $\mathrm{Hg}$ mining areas and as high as 3,100 $\mu \mathrm{g} / \mathrm{kg} \mathrm{MeHg}$ has been reported in calcines (Gray et al., 2006;). Owing to the extremely high Hg, particularly MeHg, mine-waste calcines have become major sources of $\mathrm{Hg}$ to the environment surrounding mines, causing elevated concentrations of both inorganic $\mathrm{Hg}(\mathrm{IHg})$ and MeHg in soils, water, and biota (Gibb et al., 2011; Xu et al., 2017; Qian et al., 2018; Li et al., 2020). Numerous investigations have revealed elevated high concentrations of THg in wild plants, for instance, concentrations in goosefoots (Chenopodium glaucum) and ferns (Pteris vittata L.) from the Wanshan $\mathrm{Hg}$ mining region reached $100 \mathrm{mg} / \mathrm{kg}$ (Wang et al., 2011; Qian, 2020), which is 3-4 orders of magnitude higher than the limit of $0.05 \mathrm{mg} / \mathrm{kg}$ in edible plants set by the Ministry of Health of China (2017). However, only a few studies have focused on plants MeHg, and most of them concentrated on rice, of which high levels of $\mathrm{MeHg}$ can accumulate in the grain (Li et al., 2017). Currently, data for $\mathrm{MeHg}$ in wild plants from $\mathrm{Hg}$-contaminated sites is considerably lacking.

Plants provide the basic food energy for animals occupying the areas of former $\mathrm{Hg}$ mining. The consumption of the extremely $\mathrm{Hg}$ contaminated forage-plants that may cause $\mathrm{Hg}$ accumulation and biomagnification in primary consumers, which could then enter terrestrial food chains. Mercury, as a long-term hazard in vegetated wastes, may have critical impacts on wildlife dependent on the region (Madejón et al., 2012; Basri et al., 2020). Our recent investigations have shown that MeHg has accumulated in the herbivorous

Page 2/18 
wildlife in the Wanshan $\mathrm{Hg}$ mining region to levels that could cause health effects (Abeysinghe et al., 2017; Xu et al., 2019). To better understand the potential risks of $\mathrm{THg}$ and $\mathrm{MeHg}$ exposure to herbivorous wildlife as well as livestock, the characterization of $\mathrm{THg}$ and $\mathrm{MeHg}$ in wild plants (forages) is an urgent necessity. It is important to know if forage-plants in contaminated regions are of concern for herbivores.

In the present study, dominant wild forage plants growing on wastelands in the Wanshan $\mathrm{Hg}$ mining district, Southwest China were investigated. The objectives were to (1) obtain basic information on the forage plants present and their THg and MeHg levels, (2) elucidate the transfer efficiency of $\mathrm{THg}$ and $\mathrm{MeHg}$ from the soil to the forage species and factors influencing this, and (3) clarify which species are of the greatest concern to herbivorous animals and assess the potential risk of exposure.

\section{Materials And Methods}

\subsection{Study area}

The Wanshan $\mathrm{Hg}$ mining district, on the eastern edge of the Yun-Gui Plateau in southwestern China (E: $109^{\circ} 07^{\prime}-109^{\circ} 24^{\prime} ; \mathrm{N}^{\prime}: 27^{\circ} 24^{\prime}-27^{\circ}$ $\left.38^{\prime}\right)$, is the largest industrial metallic $\mathrm{Hg}$ production center in China. This region has a typical karst landscape with an average elevation of $850 \mathrm{~m}$. The annual average temperature is $13.4^{\circ} \mathrm{C}$, and the mean annual precipitation is $1,400 \mathrm{~mm} /$ year. Cinnabar is the main ore mineral associated with metacinnabar, natural metallic $\mathrm{Hg}$, tiemannite, sphalerite, pyrite, and stibnite. The average $\mathrm{Hg}$ grade of the ore deposits is higher than $0.25 \%$.

Extensive $\mathrm{Hg}$ mining and retorting occurred for 630 years and ceased in 2004. Approximately 125.8 million tonnes of mine-waste calcines were introduced into the environment between the early 1950s and the late 1990s (Qiu et al., 2005). The large historic Hg mining adits of Lengfengdong and Meizixi are headwaters of the rivers Xiaxi and Aozhai, the major aquatic systems in the Wanshan mining district. Large mine-waste calcine piles were placed adjacent to the corresponding adits and generated a significant amount of $\mathrm{Hg}$-contaminated wastelands. In the present study, the wastelands generated by the calcine piles from Lengfengdong (LFD), Chongjiao (CJ), and Meizixi (MZX) were selected for investigation (Fig. 1; Table S1).

\subsection{Sampling and preparation}

Ninety-five samples of dominant forage plants belonging to 22 species of 18 families, which are favored by grazing animals, were collected from the wastelands. We preferentially sampled herbaceous plants rather than woody species. All of the plants were identified to the species level based on descriptions in the Flora of China (flora.huh.harvard.edu/china/mss/welcome.htm).

During sampling, dominant forage samples were randomly taken from the wastelands, within a sampling grid of $5 \times 5 \mathrm{~m}$. For each sample, three or more similarly sized individual plants of the same species were collected to ensure adequate amounts of tissue for analysis. Plant samples were dug out of the ground with a shovel and separated in situ into aboveground parts (shoots) and roots. In the laboratory, the plants were washed thoroughly with tap water and then with deionized water (DW) three times. Afterwards, the plants were frozen in a freezer and then placed in a vacuum freeze drier $\left(-50^{\circ} \mathrm{C}\right)$ for drying. The dry plants were ground and sieved to fine powders using an analytical mill (IKA-A11 basic, IKA, Germany) and nylon sieve (mesh size of $0.18 \mathrm{~mm}$ ). During processing, the lab equipment was rinsed three times with ethanol cleansing to control cross-contamination among the samples. The fine powder samples were stored in hermetic bags for analysis.

Corresponding rhizosphere soils were simultaneously collected with the plants. Approximately $0.5 \mathrm{~kg}$ of rhizosphere soil from the roots of each individual plant was shaken onto a piece of paper, and then the total $1.5 \mathrm{~kg}$ of soil collected from the 3 individual plant roots mentioned above was mixed as the final composite sample. The soils were stored in double polyethylene plastic bags to prevent any cross-contamination. After collection, all of the soil samples were air-dried in the laboratory, thoroughly mixed, and subsequently ground to fine powders using an agate mortar and nylon sieve (mesh size of $0.075 \mathrm{~mm}$ ). A cleansing process similar to the plant samples preparation was applied to control cross-contamination among the samples. The fine powder samples were stored in double zip lock polyethylene plastic bags for analysis.

\subsection{Sample analysis}

\subsubsection{Plant}


For THg determination, approximately $0.1-0.2 \mathrm{~g}$ (accurate to 0.0001) samples were weighed into plastic tubes and digested with 5 $\mathrm{mL} \mathrm{HNO} 3: \mathrm{H}_{2} \mathrm{SO}_{4}=4: 1(\mathrm{v} / \mathrm{V})$ in a water bath at $95^{\circ} \mathrm{C}$ for $3 \mathrm{~h}$. Afterwards, $5 \mathrm{~mL} \mathrm{DW}$ and $0.5 \mathrm{~mL} \mathrm{BrCl}$ were added to the solutions and they were digested for another $30 \mathrm{~min}$. Finally, the digestion solution was brought to a fixed volume of $50 \mathrm{~mL}$ with DW. After leaving the digestion for $24 \mathrm{~h}, 400 \mu \mathrm{L} \mathrm{NH} \mathrm{N}_{2} \mathrm{OH} \cdot \mathrm{HCl}$ was added, and $5.0 \mathrm{~mL}$ of the liquid supernatant was transferred to a bubble bottle. Then, $400 \mu \mathrm{L} \mathrm{SnCl} 2$ was added for $\mathrm{Hg}$ determination by atomic absorption spectroscopy (AAS, F732-V, Shanghai Huaguang, China) (Qiu et al., 2012).

For MeHg determination, approximately $0.3-0.5 \mathrm{~g}$ (accurate to 0.0001 ) samples were weighed into Teflon tubes, and a $5 \mathrm{~mL}$ methanol solution with $25 \% \mathrm{KOH}$ was added. The samples were digested for $3 \mathrm{~h}$ in a water bath at $75^{\circ} \mathrm{C}$, and then, $1.5 \mathrm{~mL}$ of concentrated $\mathrm{HCl}$ was added to acidify the solution. Subsequently, $10 \mathrm{~mL}$ of $\mathrm{CH}_{2} \mathrm{Cl}_{2}$ was added to the digestate, shaken for 30 min, and then separated. The lower solvent phase $\mathrm{CH}_{2} \mathrm{Cl}_{2}$ was collected in a $50 \mathrm{~mL}$ Teflon bottle. Approximately $30 \mathrm{~mL}$ of DW was added to the solvent phase in the $50 \mathrm{~mL}$ Teflon bottle, and then the MeHg was back-extracted into the new water phase with a fixed volume of $50 \mathrm{~mL}$. Approximately $10 \mathrm{~mL}$ samples were placed into a bubbler for MeHg determination by gas chromatography-cold vapor atomic fluorescence spectroscopy (GC-CVAFS) according to the US EPA method 1630 (Liang et al., 1996; USEPA, 2001) by using a Brooks Rand Model III mercury detector (Seattle, USA) followed with a progressive sequence of aqueous phase ethylation, addition of $2 \mathrm{M}$ acetate buffer, ethylation with $1 \%$ sodium tetraethylborate. The methylethylmercury was purged onto Tenax traps, from which it was subsequently thermally desorbed and separated for $\mathrm{MeHg}$ detection.

The bioaccumulation of heavy metals from soil can be described using bioconcentration factors (BCFs) and transfer factors (TFs) (Yoon et al., 2006; Gonzaga et al., 2008). To calculate BCFs and TFs of the plants, inorganic Hg (IHg) was calculated. Here we defined $\mathrm{IHg}$ as the difference between THg and MeHg in both the plant roots and shoots according to Lin et al. (2008) and Shi et al. (2005a, b).

\subsubsection{Soil}

For THg determination, approximately $0.1-0.2 \mathrm{~g}$ (accurate to $0.0001 \mathrm{~g}$ ) soil samples were weighed and placed into plastic tubes. Then, $5 \mathrm{~mL} \mathrm{DW}$ and $5 \mathrm{~mL}$ fresh aqua regia $\left(\mathrm{HCl}: \mathrm{HNO}_{3}=3: 1, v / v\right)$ were added. The samples were rested for $5 \mathrm{~min}$, and then, $1 \mathrm{~mL}$ $\mathrm{BrCl}$ was added for water bath digestion at $95^{\circ} \mathrm{C}$ for $3 \mathrm{~h}$. The digestate was left for $24 \mathrm{~h}$. Following this, $400 \mu \mathrm{L} \mathrm{NH} \mathrm{H}_{2} \mathrm{OH} \cdot \mathrm{HCl}$ was added to remove the free halogens, and the samples were brought to a fixed volume of $50 \mathrm{~mL}$ with DW. Approximately $5 \mathrm{~mL}$ of the digestate was taken for $\mathrm{Hg}$ analysis, similar to the methods used for the plants.

For MeHg determination, approximately $0.3-0.4 \mathrm{~g}$ (accurate to 0.0001 ) soil samples were weighed and placed into $50 \mathrm{~mL}$ plastic centrifuge tubes. Next, $1 \mathrm{~mL}$ of $2 \mathrm{~mol} / \mathrm{L} \mathrm{CuSO}_{4}$ and $4 \mathrm{~mL}$ concentrated $\mathrm{HNO}_{3}: \mathrm{H}_{2} \mathrm{O}=1: 3(\mathrm{v} / \mathrm{v})$ were added. Then, $5 \mathrm{~mL}$ ultra-pure $\mathrm{CH}_{2} \mathrm{Cl}_{2}$ was added and shaken for 30 min to extract the $\mathrm{MeHg}$ into the solvent. Afterwards, the $\mathrm{CH}_{2} \mathrm{Cl}_{2}$ solvent phase was collected in a $50 \mathrm{~mL}$ Teflon bottle. Approximately $30 \mathrm{~mL}$ of DW was added and then the MeHg was back-extracted into the new water phase. The extract was brought to a fixed volume of $50 \mathrm{~mL}$ with DW (Liang et al., 1996). Approximately $5 \mathrm{~mL}$ aliquots were taken for MeHg GCCVAFS analysis, similar to the procedure used for the plants.

For the soil pH measurements, approximately $10 \mathrm{~g}$ soil samples were weighed and placed into plastic vials. Next, $25 \mathrm{~mL}$ of $\mathrm{DW}$ without $\mathrm{CO}_{2}$ was added, mixed for $2 \mathrm{~min}$, and left to settle for $30 \mathrm{~min}$ (Lu, 2000). The soil pH was determined using a pH meter (PHS3E, Shanghai Leici, China).

For soil organic matter (OM) determination, approximately $0.5-1.0 \mathrm{~g}$ of soil was weighed and placed into colorimetric tubes. Concentrated sulfuric acid was added and then $\mathrm{OM}$ measurement followed a water bath-potassium dichromate volumetric method (Lu, 2000).

\subsection{Quality Assurance/Quality Control}

Quality assurance/quality control (QA/QC) measures employed consisted of the use of a standard working curve, blanks, sample duplicates, matrix spikes, and the certified reference materials of lichen (BCR-482), lobster hepatopancreas (TORT-2), Chinese yellowred soil (GBW07405), and estuarine sediment (ERM-CC580), as further described below and in the Supplementary Material (Table S2).

For THg, the method was validated using the reference materials BCR-482 and GBW07405. An average total Hg concentration of $0.475 \pm 0.02 \mathrm{mg} / \mathrm{kg}(\mathrm{n}=5)$ was obtained for the lichen standard BCR-482, which was within the range of the certified value of $0.48 \pm$ 
$0.02 \mathrm{mg} / \mathrm{kg}$. For the soil, GBW07405 was used, and the measured concentration of $0.32 \pm 0.02 \mathrm{mg} / \mathrm{kg}(\mathrm{n}=5)$ was within acceptable range of the certified value of $0.29 \pm 0.04 \mathrm{mg} / \mathrm{kg}$.

For MeHg, the obtained value of $75.0 \pm 3.1 \mu \mathrm{g} / \mathrm{kg}(\mathrm{n}=5)$ met the certified value of $75.5 \pm 3.7 \mu \mathrm{g} / \mathrm{kg}$ for the ERMCC-580 soil standard. In addition, the obtained value of $155 \pm 25 \mu \mathrm{g} / \mathrm{kg}(\mathrm{n}=5)$ met the certified value of $152 \pm 13 \mu \mathrm{g} / \mathrm{kg}$ for the TORT-2 plant standard. The recovery of $\mathrm{THg}$ and $\mathrm{MeHg}$ in the solid samples was in the range of $95-109 \%$, and $87-108 \%$, respectively.

\subsection{Calculations of BCFs and TFs of $\mathrm{IHg}$ and $\mathrm{MeHg}$}

In the present study, the $\mathrm{IHg}$ and MeHg BCFs were defined as the ratios of their concentration in the plant roots to that in the soil ([IHg or $\mathrm{MeHg}_{\text {root }} /\left[\mathrm{IHg}\right.$ or $\left.\mathrm{MeHg}_{\text {soil }}\right)$, reflecting the capability of the plant's roots to absorb and accumulate $\mathrm{lHg}$ and MeHg from the soil. The TFs were defined as the ratio of the $\mathrm{IHg}$ and $\mathrm{MeHg}$ concentration in the shoots of the plants to that in their roots ([IHg or $\mathrm{MeHg}_{\text {shoot }} /[\mathrm{IHg} \text { or } \mathrm{MeHg}]_{\text {root }}$ ), referring to the capability of the plant to transport $\mathrm{IHg}$ and $\mathrm{MeHg}$ from the roots to the shoots.

\subsection{Statistical analysis}

Data analyses were performed using Microsoft Excel 2010 (Microsoft Co. Ltd., USA). CorelDRAW Graphics Suits X8 (Corel Corporation, USA) was used to draw a map of the sampling sites. Other figures and a one-way ANOVA followed by Dunnett's multiple comparisons test were performed using GraphPad Prism version 8.0.0 for Windows (GraphPad Software, San Diego, USA) and R v3.6.1 (R Core Team, 2019).

\section{Results And Discussion}

\subsection{Plant species}

All of the samples belonged to 22 species of 18 families. The colonizing plants on the $\mathrm{CJ}$ wasteland consisted of 11 species Aster ageratoides, Aster subulatus, Buddleja davidii, Cibotium barometz, Conyza canadensis, Corydalis edulis Maxim, Gynura bicolor, Herba artimisiae sieversianae, Rumex japonicus, Sonchus brachyotus, and Sonchus oleraceus. These plants had high coverage and biomass, and the Asteraceae family accounted for $50.0 \%$ of them. Plants such as $C$. canadensis are amphibious plants, which have various growth habits but have a strong reproductive capacity and can grow well in places with high $\mathrm{Hg}$ concentrations. On the LFD and MZX wastelands, the dominant plants included A. ageratoides, B. davidii, H. artimisiae sieversianae, Houttuynia cordata, Oenanthe javanica, Primula sikkimensis, Portulaca oleracea, Primula sikkimensis, R. japonicas, A. subulatus, Brassica campestris, $C$. canadensis, H. cordata, Ipomoea batatas, Mentha canadensis, Plantago asiatica, Rumex acetosa, R. japonicus, Sedum bulbiferum, Sedum emarginatum, and S. oleraceus. Of these plants, the three families Asteraceae, Crassulaceae and Polygonaceae accounted for $69.2 \%$ of the total.

The wastelands used to be arable lands but currently contain a significant amount of mine-waste calcine, resulting in poor nutrient content and extremely high $\mathrm{Hg}$ concentrations. These conditions are conducive only to certain plant species with the capacity to grow in disturbed environments and with a high $\mathrm{Hg}$ tolerance. The herbaceous Asteraceae species accounted for $40 \%$ of the total investigated plants. These species exhibit particular characteristics such as abundant seeds, fast bud and growth rates, high biomass, and resilience, allowing them to become the dominant plant colonies on the wastelands.

\subsection{Concentrations of $\mathrm{THg}$ and $\mathrm{MeHg}$}

\subsubsection{THg}

THg exhibited a wide range of concentrations in the roots and shoots of the 22 species, ranging from 0.10 to $4.4 \mathrm{mg} / \mathrm{kg}$ and 0.19 to $13 \mathrm{mg} / \mathrm{kg}$, respectively (Table 1; Fig. 2a). Compared with the average THg values among the different species, the shoots of $A$. ageratoides showed the highest THg level, reaching $12 \pm 1.1 \mathrm{mg} / \mathrm{kg}$, followed by $P$. sikkimensis with $6.7 \pm 1.2 \mathrm{mg} / \mathrm{kg}$, while the lowest $\mathrm{THg}$ level was in A. subulatus with $0.39 \pm 0.055 \mathrm{mg} / \mathrm{kg}$. The A. ageratoides roots also showed the highest THg level of $3.8 \pm 0.69$ $\mathrm{mg} / \mathrm{kg}$, on average, while the lowest THg level of $0.13 \pm 0.052 \mathrm{mg} / \mathrm{kg}$ was in $B$. campestris. One-Way ANOVA tests showed no differences in the THg concentrations in both the roots and shoots of the plants among the different wastelands, even though significant differences in soil THg were observed between CJ and MZX $(P=0.0007)$, and between LFD and MZX $(P=0.0108)($ Table 3; Figure S1). A positive correlation was detected between the shoots and roots $\left(r^{2}=0.48, P<0.0001\right.$; Fig. 3a). 
Table 1

Concentrations of THg and its BCFs and TFs in wild plants inhabiting the wastelands of the Wanshan $\mathrm{Hg}$ mining region, Guizhou Province, Southwest China $(\mathrm{mg} / \mathrm{kg})$

\begin{tabular}{|llllll|}
\hline Species (acronym) & Soil & Root & Shoot & BCFs & TFs \\
\hline Aster ageratoides (A.a) & $32 \pm 5.6$ & $3.8 \pm 0.69$ & $12 \pm 1.1$ & $0.12 \pm 0.028$ & $3.1 \pm 0.37$ \\
\hline Aster subulatus (A.s) & $34 \pm 6.5$ & $2.3 \pm 0.76$ & $0.39 \pm 0.055$ & $0.065 \pm 0.018$ & $0.19 \pm 0.09$ \\
\hline Brassica campestris L. (B.C) & $24 \pm 7.1$ & $0.13 \pm 0.052$ & $1.4 \pm 0.34$ & $0.006 \pm 0.002$ & $11 \pm 1.9$ \\
\hline Buddleja daviddii (B.d) & $46 \pm 14$ & $0.58 \pm 0.26$ & $2.5 \pm 0.91$ & $0.013 \pm 0.004$ & $4.5 \pm 1.4$ \\
\hline Cibotium barometz L. (C.b) & $37 \pm 3.5$ & $1.6 \pm 0.26$ & $3.4 \pm 0.46$ & $0.043 \pm 0.011$ & $2.2 \pm 0.072$ \\
\hline Conyza canadensis (C.c) & $31 \pm 15$ & $1.2 \pm 0.50$ & $1.4 \pm 0.71$ & $0.040 \pm 0.012$ & $1.3 \pm 0.47$ \\
\hline Corydalis edulis Maxim. (C.e) & $24 \pm 5.7$ & $0.15 \pm 0.038$ & $0.69 \pm 0.30$ & $0.006 \pm 0.003$ & $4.5 \pm 1.1$ \\
\hline Gynura bicolor (G.b) & $43 \pm 5.5$ & $0.86 \pm 0.11$ & $0.76 \pm 0.11$ & $0.019 \pm 0.001$ & $0.90 \pm 0.22$ \\
\hline Herba artimisiae (H.a) & $60 \pm 28$ & $1.7 \pm 1.1$ & $0.92 \pm 0.27$ & $0.029 \pm 0.014$ & $0.72 \pm 0.40$ \\
\hline Houttuynia cordata (H.c) & $179 \pm 39$ & $1.3 \pm 0.57$ & $1.5 \pm 0.53$ & $0.007 \pm 0.003$ & $1.4 \pm 0.86$ \\
\hline Ipomoea batatas (I.b) & $355 \pm 113$ & $3.4 \pm 0.92$ & $3.7 \pm 0.49$ & $0.010 \pm 0.003$ & $1.22 \pm 0.58$ \\
\hline Mentha canadensis (M.C) & $132 \pm 40$ & $1.1 \pm 0.32$ & $1.2 \pm 0.34$ & $0.009 \pm 0.004$ & $1.1 \pm 0.56$ \\
\hline Oenanthe javanica (O.j) & $61 \pm 21$ & $0.92 \pm 0.040$ & $0.84 \pm 0.041$ & $0.02 \pm 0.0008$ & $0.92 \pm 0.08$ \\
\hline Plantago asiatica (P.a) & $159 \pm 68$ & $0.56 \pm 0.034$ & $0.45 \pm 0.070$ & $0.004 \pm 0.002$ & $0.81 \pm 0.17$ \\
\hline Portulaca oleracea (P.o) & $72 \pm 18$ & $0.83 \pm 0.13$ & $0.84 \pm 0.13$ & $0.012 \pm 0.002$ & $1.0 \pm 0.045$ \\
\hline Primula sikkimensis (P.s) & $135 \pm 17$ & $2.6 \pm 0.12$ & $6.7 \pm 1.2$ & $0.019 \pm 0.002$ & $2.7 \pm 0.64$ \\
\hline Rumex acetosa (R.a) & $85 \pm 3.9$ & $0.57 \pm 0.36$ & $0.40 \pm 0.20$ & $0.007 \pm 0.003$ & $0.73 \pm 0.18$ \\
\hline Rumex japonicus (R.j) & $47 \pm 18$ & $0.30 \pm 0.13$ & $0.93 \pm 0.57$ & $0.007 \pm 0.002$ & $3.2 \pm 1.4$ \\
\hline Sedum bulbiferum (S.bu) & $252 \pm 23$ & $0.69 \pm 0.090$ & $0.51 \pm 0.24$ & $0.003 \pm 0.0002$ & $0.72 \pm 0.27$ \\
\hline Sedum emarginatum (S.e) & $53 \pm 23$ & $0.82 \pm 0.21$ & $0.61 \pm 0.067$ & $0.017 \pm 0.007$ & $0.81 \pm 0.32$ \\
\hline Sonchus brachyotus (S.br) & $45 \pm 4.9$ & $0.58 \pm 0.29$ & $0.60 \pm 0.12$ & $0.013 \pm 0.008$ & $1.3 \pm 0.77$ \\
\hline Sonchus oleraceus (S.o) & $121 \pm 27$ & $0.67 \pm 0.22$ & $0.41 \pm 0.12$ & $0.006 \pm 0.003$ & $0.69 \pm 0.44$ \\
\hline
\end{tabular}

The plants in the present study exhibited a comparable level of $\mathrm{THg}(9.9 \mathrm{mg} / \mathrm{kg}$ on average) to that recently reported from artisanal and small-scale mining in the Bombana, Indonesia, though this was much higher than the THg levels from the Alacrán gold mining area in the USA, and those observed in agricultural plants of the same region (Marrugo-Negrete et al., 2016; Basri et al., 2020). In the study area, fresh forage-plants were the main feedstock for cattle and goats, hence, such elevated levels of $\mathrm{Hg}$ leads to high risks for potential of exposure to livestock and wildlife that consume these plants. Among the investigated forage-plant species, $A$. ageratoides recorded the highest THg concentrations both in the shoots and roots, which may be of great concern for herbivorous/omnivorous grazing animals.

\subsubsection{MeHg}

Forage-plants showed broad ranges of MeHg concentrations in the roots and shoots, ranging from 0.19 to $23 \mu \mathrm{g} / \mathrm{kg}$ and 0.28 to 11 $\mu \mathrm{g} / \mathrm{kg}$, respectively (Table 2; Fig. 2b). The highest average MeHg concentration was found in the shoots of $A$. subulatus at $7.4 \pm 6.1$ $\mu \mathrm{g} / \mathrm{kg}$, followed by $S$. brachyotus with $3.5 \pm 2.5 \mu \mathrm{g} / \mathrm{kg}$, while the lowest was in B. camperstris with $0.49 \pm 0.11 \mu \mathrm{g} / \mathrm{kg}$. S. brachyotus exhibited the highest average MeHg concentration in its roots with $13 \pm 10 \mu \mathrm{g} / \mathrm{kg}$, followed by $A$. subulatus at $9.4 \pm 8.0 \mu \mathrm{g} / \mathrm{kg}$, while the lowest was in A. ageratoides at $1.1 \pm 0.76 \mu \mathrm{g} / \mathrm{kg}$. As expected, the root MeHg exhibited a significant positive correlation to the MeHg in the shoots $\left(r^{2}=0.46, P<0.0001\right.$; Fig. $\left.3 b\right)$, suggesting a strong transport of MeHg from the roots to the aboveground parts of the plants. 
Table 2

Concentrations of $\mathrm{MeHg}$ and its BCFs and TFs in wild plants inhabiting the wastelands of the Wanshan $\mathrm{Hg}$ mining region, Guizhou Province, Southwest China $(\mu \mathrm{g} / \mathrm{kg})$

\begin{tabular}{|llllll|}
\hline Species (acronym) & Soil & Root & Shoot & BCFs & TFs \\
\hline Aster ageratoides (A.a) & $1.4 \pm 0.15$ & $1.6 \pm 0.65$ & $1.8 \pm 1.1$ & $1.2 \pm 0.58$ & $1.1 \pm 0.45$ \\
\hline Aster subulatus (A.s) & $0.78 \pm 0.055$ & $11.4 \pm 2.8$ & $11 \pm 0.53$ & $14 \pm 2.5$ & $0.97 \pm 0.18$ \\
\hline Brassica campestris L. (B.c) & $5.8 \pm 2.7$ & $0.79 \pm 0.18$ & $0.49 \pm 0.11$ & $0.16 \pm 0.088$ & $0.63 \pm 0.006$ \\
\hline Buddleja daviddii (B.d) & $2.8 \pm 2.1$ & $2.6 \pm 0.69$ & $2.2 \pm 0.81$ & $1.3 \pm 0.68$ & $0.98 \pm 0.56$ \\
\hline Cibotium barometz L. (C.b) & $16 \pm 11$ & $1.1 \pm 0.18$ & $1.2 \pm 0.67$ & $0.16 \pm 0.21$ & $1.1 \pm 0.45$ \\
\hline Conyza canadensis (C.c) & $2.9 \pm 1.3$ & $1.9 \pm 1.22$ & $2.1 \pm 0.87$ & $0.82 \pm 0.71$ & $1.7 \pm 1.4$ \\
\hline Corydalis edulis Maxim. (C.e) & $10 \pm 1.2$ & $6.3 \pm 0.57$ & $4.9 \pm 0.42$ & $0.63 \pm 0.038$ & $0.77 \pm 0.066$ \\
\hline Gynura bicolor (G.b) & $11 \pm 0.99$ & $3.8 \pm 0.77$ & $1.2 \pm 0.21$ & $0.34 \pm 0.10$ & $0.32 \pm 0.10$ \\
\hline Herba artimisiae (H.a) & $5.0 \pm 2.4$ & $2.4 \pm 1.2$ & $1.5 \pm 1.0$ & $0.76 \pm 0.73$ & $0.62 \pm 0.20$ \\
\hline Houttuynia cordata (H.C) & $4.9 \pm 2.3$ & $2.6 \pm 2.1$ & $1.3 \pm 0.71$ & $0.73 \pm 0.72$ & $0.77 \pm 0.54$ \\
\hline Ipomoea batata (I.b) & $18 \pm 2.2$ & $2.3 \pm 0.71$ & $4.2 \pm 1.4$ & $0.13 \pm 0.049$ & $1.9 \pm 1.1$ \\
\hline Mentha canadensis (M.c) & $2.9 \pm 0.90$ & $0.97 \pm 0.34$ & $1.1 \pm 0.36$ & $0.36 \pm 0.18$ & $1.1 \pm 0.34$ \\
\hline Oenanthe javanica (O.j) & $2.9 \pm 2.3$ & $1.7 \pm 0.057$ & $2.9 \pm 0.70$ & $0.80 \pm 0.42$ & $1.8 \pm 0.37$ \\
\hline Plantago asiatica (P.a) & $4.4 \pm 1.6$ & $1.2 \pm 0.79$ & $0.59 \pm 0.19$ & $0.38 \pm 0.36$ & $0.67 \pm 0.43$ \\
\hline Portulaca oleracea (P.o) & $2.8 \pm 0.58$ & $6.6 \pm 1.6$ & $2.3 \pm 0.62$ & $2.4 \pm 0.48$ & $0.37 \pm 0.10$ \\
\hline Primula sikkimensis (P.s) & $3.8 \pm 0.87$ & $2.1 \pm 1.1$ & $1.5 \pm 0.18$ & $0.52 \pm 0.18$ & $0.85 \pm 0.38$ \\
\hline Rumex acetosa (R.a) & $4.0 \pm 1.5$ & $1.8 \pm 2.5$ & $0.75 \pm 0.27$ & $0.38 \pm 0.44$ & $1.1 \pm 0.79$ \\
\hline Rumex japonicus (R.j) & $2.2 \pm 1.7$ & $3.8 \pm 2.5$ & $1.5 \pm 0.57$ & $2.4 \pm 2.3$ & $0.66 \pm 0.49$ \\
\hline Sedum bulbiferum (S.bu) & $4.4 \pm 0.82$ & $2.2 \pm 0.77$ & $1.3 \pm 0.22$ & $0.50 \pm 0.18$ & $0.66 \pm 0.23$ \\
\hline Sedum emarginatum (S.e) & $2.1 \pm 0.30$ & $3.2 \pm 1.8$ & $0.94 \pm 0.38$ & $1.5 \pm 0.66$ & $0.33 \pm 0.15$ \\
\hline Sonchus brachyotus (S.br) & $5.9 \pm 2.2$ & $19 \pm 2.6$ & $6.5 \pm 1.1$ & $3.8 \pm 1.8$ & $0.34 \pm 0.088$ \\
\hline Sonchus oleraceus (S.o) & $2.5 \pm 1.5$ & $1.9 \pm 1.1$ & $2.9 \pm 1.9$ & $0.79 \pm 0.26$ & $1.5 \pm 0.45$ \\
\hline
\end{tabular}

Different species exhibited different capabilities for MeHg bioaccumulation. In addition to A. subulatus, which recorded the highest levels of MeHg concentration (greater than $10 \mu \mathrm{g} / \mathrm{kg}$ on average) in both the shoots and roots, species $S$. brachyotus, $C$. edulis, and $P$. oleracea also showed high MeHg concentrations, particularly in their roots, with a range of $6.3-19 \mu \mathrm{g} / \mathrm{kg}$ on average. Those values were comparable to those observed in rice in the same region (Zhao et al., 2016; Xu et al., 2017). Such significantly high levels of $\mathrm{MeHg}$ in both the shoots and roots may result in heavy MeHg body burdens in herbivores as well as their predators because of how easily it is absorbed and accumulated by organisms. This may be an explanation of the high MeHg levels in herbivores identified in the study region in the report by Abeysinghe et al. (2017). 
Table 3

$\mathrm{THg}$ and $\mathrm{MeHg}$ concentrations in the plants as well as their rhizosphere soils from the three sampling sites of the Wanshan Hg mining region, Gizhou Province, Southwest China

\begin{tabular}{|c|c|c|c|c|c|c|c|c|c|c|}
\hline \multirow[t]{2}{*}{ Conc. } & & \multicolumn{3}{|c|}{ Chongjiao } & \multicolumn{3}{|c|}{ Lengfengdong } & \multicolumn{3}{|l|}{ Meizixi } \\
\hline & & Soil & Root & Shoot & Soil & Root & Shoot & Soil & Root & Shoot \\
\hline \multirow[t]{4}{*}{$\mathrm{THg}(\mathrm{mg} / \mathrm{kg})$} & Minimum & 14 & 0.56 & 0.61 & 24 & 0.19 & 0.19 & 16 & 0.1 & 0.24 \\
\hline & Median & 40 & 0.80 & 0.89 & 57 & 0.81 & 0.95 & 105 & 0.84 & 0.70 \\
\hline & Maximum & 308 & 23 & 11 & 176 & 4.4 & 13 & 456 & 4.1 & 5.6 \\
\hline & Mean $\pm S D$ & $57 \pm 56$ & $4.8 \pm 6.1$ & $3.3 \pm 2.6$ & $73 \pm 47$ & $1.2 \pm 1.1$ & $2.8 \pm 3.7$ & $133 \pm 104$ & $1.2 \pm 0.96$ & $1.1 \pm 1.0$ \\
\hline \multirow[t]{4}{*}{$\mathrm{MeHg}(\mu \mathrm{g} / \mathrm{kg})$} & Minimum & 0.74 & 0.56 & 0.61 & 1.2 & 0.94 & 0.81 & 0.75 & 0.19 & 0.28 \\
\hline & Median & 4.7 & 2.0 & 2.7 & 2.2 & 3.4 & 2.1 & 3.6 & 1.9 & 0.99 \\
\hline & Maximum & 23 & 23 & 11 & 5.6 & 8.8 & 3.4 & 19 & 9.2 & 11 \\
\hline & Mean $\pm S D$ & $6.5 \pm 6.1$ & $4.8 \pm 6.0$ & $3.3 \pm 2.6$ & $2.9 \pm 1.4$ & $3.9 \pm 2.2$ & $2.1 \pm 0.75$ & $4.6 \pm 3.6$ & $2.2 \pm 1.9$ & $1.6 \pm 1.9$ \\
\hline
\end{tabular}

\subsection{BCFs and TFs for $\mathrm{IHg}$ and $\mathrm{MeHg}$}

\subsubsection{BCFs}

Plants exhibited a wide range of BCFs for $\mathrm{IHg}$ and $\mathrm{MeHg}$, ranging from 0.0023 to 0.16 and from 0.022 to 17 , respectively. The $\mathrm{BCF}$ for $\mathrm{IHg}$ in all species were less than 1 , with the highest average value in $A$. ageratoides at $0.12 \pm 0.028$. For MeHg, seven species, $A$. ageratoides, $A$. subulatus, $B$. daviddii, P. oleracea, $R$. japonicus, $S$. emarginatum, and $S$. brachyotus exhibited peak values exceeding 1.0 , ranging from 1.3 to 14 on average. The $A$. subulatus showed the highest MeHg BCF of $14 \pm 2.5$, on average, followed by $S$. brachyotus with $3.8 \pm 1.8$, while the lowest value of $0.13 \pm 0.049$ was in I. batatas (Tables $1 \& 2 ;$ Fig. 4). The extent of bioaccumulation of MeHg in plants is likely dependent on the species. Previous studies have reported that BCFs of THg and/or IHg in plants are usually lower than 0.5 (Zhang et al., 2010; Cosio et al., 2014), while the BCFs of MeHg were usually higher than that of THg and/or IHg (Schwesig and Krebs, 2003; Tong et al., 2013), which was in agreement with our data.

\subsubsection{TFs}

The TFs for IHg in the plants varied widely, ranging between 0.12 and 13 . The lowest TF value differed from the highest by more than 100 times. Most of the species exhibited average values of TF greater than 1 , and among them, $B$. campestris exhibited the highest value of $11 \pm 1.9$ on average. For MeHg, eight species exhibited peak values exceeding 1.0 , ranging from 1.1 to 1.9 , with the highest value observed in I. batatas (Tables 1 \& 2; Fig. 4). Five species, A. ageratoides, C. barometz, C. canadensis, I. batatas, and M. canadesis showed high TFs for both $\mathrm{IHg}$ and $\mathrm{MeHg}$ with peak values exceeding 1.0 on average, indicating their increased ability to accumulate $\mathrm{IHg}$ and $\mathrm{MeHg}$ compared with that of other species.

For all of the species, the MeHg in the roots was at higher concentrations than that observed in the shoots, and the MeHg showed significantly higher BCFs than that of $\mathrm{IHg}$, confirming that $\mathrm{MeHg}$ is more easily absorbed by the roots. Plant roots can absorb MeHg from the soil and the total amount of MeHg in the soil plays a critical role in controlling MeHg concentrations in rice (Meng et al., 2011). At highly Hg-contaminated sites, high amounts of $\mathrm{MeHg}$ can be generated due to the active methylation occurring in the water and soil, which could eventually lead to increased MeHg accumulation in plants.

Although all of the plants were capable of growing in a heavily Hg-contaminated environment, the significant variation in the Hg concentrations may be due to the different physiological characteristics of the plants (Marrugo-Negrete et al., 2016). Mercury is a unique heavy metal that can exist in its elemental form in the atmosphere, so mining and retorting activities resulted in an even further increase in the atmospheric $\mathrm{Hg}$ (i.e., 1-3 orders of magnitude higher than in the remote regions; Zhang et al., 2016; Xu et al., 2020). Hence, the finding that the shoots of the plants exhibited higher IHg concentrations than those of the roots, in the present study, may be attributed to the elevated levels of atmospheric Hg, which can also explain the elevated TFs for IHg (Fig. 5).

\subsection{Correlations among Factors affecting $\mathrm{IHg}$ and $\mathrm{MeHg}$ in plants}


Rhizosphere soil Hg, as well as soil pH and OM, can affect Hg levels in plants (Zhao et al., 2016; Tang et al., 2018). The average THg concentrations in the investigated plants' rhizosphere soil ranged from 18 to $261 \mathrm{mg} / \mathrm{kg} \mathrm{THg}$ and from 1.4 to $19 \mu \mathrm{g} / \mathrm{kg} \mathrm{MeHg}$. Soil pH values were all higher than 7.5 , due to the carbonate buffering of the surrounding rock and the introduction of large amounts of MgO and $\mathrm{CaO}$ during the retorting of cinnabar ores.

Spearman correlation coefficients of the $\mathrm{Hg}$ concentrations with the bioaccumulation factors are shown in Fig. 6 . Roots $\mathrm{IHg}$ had the most significant correlations with the shoots $\mathrm{IHg}(r=0.7, P<0.01)$ and $\mathrm{IHg} \mathrm{BCFs}(r=0.66, P<0.01)$, as well as positive correlations with soil THg $(r=0.31, P<0.01)$ and MeHg $(r=0.24, P<0.05)$, and negative correlation with $\mathrm{Hg} \mathrm{TFs}(\mathrm{r}=-0.22, P<0.05)$, signifying their contributions to the accumulation of $\mathrm{Hg}$ in the roots. Shoot $\mathrm{IHg}$ had fewer correlations with other parameters, showing positive correlations only with IHg BCFs $(r=0.7, P<0.01)$ and IHg TFs $(r=0.22, P<0.05)$. The concentrations of root MeHg also exhibited a strong positive correlation to MeHg BCFs as well as shoot MeHg. Interestingly, soil pH exhibited positive correlations to both root MeHg $(r=0.25, P<0.05)$ and shoot MeHg $(r=0.34, P<0.01)$, and likewise to MeHg TFs $(r=0.22, P<0.05)$ as well as MeHg BCFs $(r=$ $0.17, P<0.05)$, suggesting that $\mathrm{pH}$ was an important factor for controlling the processes of plant $\mathrm{MeHg}$ uptake and transport from the soil into the body. In contrast, soil OM showed negative correlations to both MeHg BCFs $(r=-0.29, P<0.01)$ and MeHg TFs $(r=-0.32, P<$ 0.01), as well as shoot MeHg $(r=-0.34, P<0.01)$.

In the present study, though soil $\mathrm{Hg}$ played an important role in the absorption and enrichment of $\mathrm{Hg}$ in the plants, it was found that the rhizosphere soil $\mathrm{pH}$ and $\mathrm{OM}$ may also play important roles in the process of $\mathrm{Hg}$ uptake and transfer in plants. Our results indicate that there is a complex mechanism for $\mathrm{Hg}$ uptake, particularly for plants growing in heavily Hg-contaminated sites.

\subsection{Potential risks for herbivores}

The forage plants investigated in the present study are usually consumed by domestic animals such as cows, goats, and poultry. Based on the ecotoxicological effects of $\mathrm{Hg}$ on organisms, De Vries et al. (2002) recommended a set of critical limits for $\mathrm{Hg}$ in plants, and categorized $\mathrm{Hg}$ concentrations into three hazard levels: high hazard (>3 mg/kg), low-moderate hazard (0.1-3.0 mg/kg), and low hazard $(<0.1 \mathrm{mg} / \mathrm{kg}$ ). Considering the shoots, all of the investigated species of forage plant were at a low-moderate or greater hazard level, with approximately $15.8 \%$ of them falling into the high hazard level with greater than $3 \mathrm{mg} / \mathrm{kg} \mathrm{Hg}$. Moreover, compared to the national permitted limit of $0.1 \mathrm{mg} / \mathrm{kg}$ THg in vegetables (GB $2762-2017$ ), the average THg concentration in the shoots of most the forage-plant species was elevated by $2-3$ orders of magnitude.

Four species, A. ageratoides, P. sikkimensis, I. batatas, and C. barometz, exhibited THg greater than $3 \mathrm{mg} / \mathrm{kg}$ in their shoots, suggesting that these plants had high $\mathrm{Hg}$ accumulation capabilities. These species are generally characterized by cold, droughttolerance, large biomass, and long growing period (Xing et al., 2010; Wang et al., 2011), resulting in their strong growth on the wastelands. Hence, the high concentrations of $\mathrm{Hg}$ in their shoots may cause potentially high $\mathrm{Hg}$ exposure risks to herbivorous/omnivorous wildlife and feeding livestock.

Currently, critical limits for $\mathrm{Hg}$ in plants (grass) for grazing animals are not available. Therefore, JECFA PTWI values for human intake were cited in the risk assessment for herbivores (Gramss and Voigt, 2014). Taking the provisional tolerable weekly intake (PTWI) value $4 \mathrm{ng} / \mathrm{g}$ for IHg recommended by the JECFA (2010) for human dietary exposure from foods other than fish and shellfish into account, daily ingestion of $0.037 \mu \mathrm{g} \mathrm{IHg}$ by a $65 \mathrm{~kg}$ animal is acceptable. Grazing on $1.0 \mathrm{~kg}$ of the shoots of the forage-plants (dry weight) would mean that the daily intake of $\mathrm{IHg}$ and $\mathrm{MeHg}$ was between 190-13200 $\mu \mathrm{g}$, which reaches 3-5 orders of magnitude higher than the permitted limit. Moreover, grazing animals, such as cows and sheep are highly sensitive to contamination due to the ingestion of soil along with grass intake, hence, the heavily contaminated soil with both $\mathrm{THg}$ and $\mathrm{MeHg}$ is another point of concern.

\section{Conclusions}

The dominant forage plants collected from the wastelands of this world large-scale $\mathrm{Hg}$ mine exhibited high concentrations of both $\mathrm{THg}$ and $\mathrm{MeHg}$, ranging from 0.085 to $13 \mathrm{mg} / \mathrm{kg}$ and 0.059 to $24 \mu \mathrm{g} / \mathrm{kg}$, respectively. Species A. ageratoides, C. barometz, I. batatas, and $P$. sikkimensis exhibited THg greater than the high hazard level of $3 \mathrm{mg} / \mathrm{kg}$ in their shoots. Moreover, comparable levels of MeHg in $A$. subulatus, $C$. edulis, $S$. brachyotus, and $P$. oleracea to that found in rice were observed. Among of those species, $A$. ageratoides, C. barometz, and I. batatas showed high abilities to accumulate and transfer both $\mathrm{HH}$ and $\mathrm{MeHg}$ to their shoots, with their TFs being greater than 1.0. The species $A$. ageratoides, $A$. subulatus, and $S$. brachyotus in the present study may pose the highest risks for $\mathrm{THg}$ and $\mathrm{MeHg}$ exposure to biota due to their strong $\mathrm{Hg}$ accumulation abilities and abundant biomass. Because the investigated forage

Page 9/18 
plants were widely consumed by herbivorous/omnivorous wildlife and feeding livestock, the high $\mathrm{THg}$ and MeHg concentrations could directly result in $\mathrm{Hg}$ accumulation and biomagnification in the terrestrial food chain. Thus, future studies on the plantherbivorous-carnivorous food chain are urgently needed to clarify the risks from $\mathrm{THg}$, and particularly MeHg, exposure to wildlife and feeding livestock.

\section{Declarations}

\section{Acknowledgements:}

Financial support for this work was provided by the talent introduction research project of Guizhou University (2019: 06), the National Key Research and Development Plan [2018YFC1802602], the First-Class Ecology Discipline in Guizhou Province (No.

GNYL[2017]007), and the National Natural Science Foundation of China (NSFC: 41573135).

\section{Declaration of Interest}

The authors declare that they have no conflict of interests or personal relationships that could have influenced the work reported in the manuscript - "Extremely elevated total mercury and methylmercury in forage plants in a world large-scale abandoned $\mathrm{Hg}$ mining site: A potential risk of exposure to grazing animals"

\section{References}

1. Abeysinghe KS, Qiu G, Goodale E, Anderson CWN, Bishop K, Evers D, Goodale M, Hintelmann H, Liu S, Mammides C, Quan R, Wang J, Wu P, Xu X, Yang X, Feng X (2017) Mercury flow through an Asian rice-based food web. Environ Pollut 229:219-228.

2. Agency for Toxic Substances and Disease Registry (ATSDR) (2013) Addendum for organic mercury compounds (alkyl and dialkyl mercury compounds). Supplement to the 1999 toxicological profile for mercury. Atlanta, GA. http://www.atsdr.cdc.gov/toxprofiles/mercury_organic_addendum.pdf 143.

3. Basri MS, Koihiro S (2020) Mercury in soil and forage plants from artisanal and small-scale gold mining in the bombana area, Indonesia. Toxicol 8(1):15-19.

4. Conko KM, Landa ER, Kolker A, Kozlov K, Gibb HJ, Centeno JA, Panov BS, Panov YB (2013) Arsenic and mercury in the soils of an industrial city in the Donets Basin, Ukraine. Soil. Sedim. Contam: An International Journal 22(5):574-593

5. Cosio C, Flück R, Regier N, Slaveykova VI (2014) Effects of macrophytes on the fate of mercury in aquatic systems. Environ Toxicol Chem 33(6):1225-1237.

6. De Vries W, Schütze G, Lofts S, Meili M, Römkens P, Farret R, De Temmerman L, Jakubowski M (2003) Critical limits for cadmium, lead, and mercury related to ecotoxicological effects on soil organisms, aquatic organisms, plants, animals and humans. In: Background document for the "Expert meeting on critical limits for heavy metals and methods for their application". -Berlin 2-4 December 2002, held under the UNECE Convention on long range transboundary air pollution, pp1-61.

7. Driscoll CT, Mason RP, Chan HM, Jacob DJ, Pirrone N (2013) Mercury as a global pollutant: sources, pathways, and effects. Environ Sci Technol 47(10):4967-4983.

8. GB2762-2017 (2017) National Safety Standards for Foods and Maximum Levels of Contaminant in Foods. Ministry of Health of the People's Republic of China.

9. Gibb H, Haver C, Kozlov K, Centeno JA, Jurgenson V, Kolker A, Conko KM, Landa ER, Xu H (2011) Biomarkers of mercury exposure in two eastern Ukraine cities. J Occupat Environ Hyg 8(4):187-193.

10. Gonzaga MIS, Santos JAG, Ma LQ (2008) Phytoextraction by arsenic hyperaccumulator Pteris vittata L. from six arseniccontaminated soils: repeated harvests and arsenic redistribution. Environ Pollut 154(2):212-218.

11. Gramss G, \& Voigt K (2014) Forage and rangeland plants from uranium mine soils: long-term hazard to herbivores and livestock? Environ Geochem Health 36:441-452.

12. Gray JE, Hines ME, Biester H (2006) Mercury methylation influenced by areas of past mercury mining in the Terlingua district, Southwest Texas, USA. Appl Geochem 21(11):1940-1954. 
13. Horvat M, Nolde N, Fajon V, Jereb V, Logar M, Lojen S, Jacimovic R,Falnoga I, Qu L, Faganeli J, Drobne D (2003) Total mercury, methymercury and selenium in mercury polluted areas in the province Guizhou, China. Sci Total Environ 304(1-3):231-256.

14. JECFA (2010) Summary and conclusions of the seventy-second meeting of the joint FAO/WHO expert committee on food additives Rome, Italy.

15. Liang L, Horvat M, Cernichiari E, Gelein B, Balogh S (1996) Simple solvent extraction technique for elimination of matrix interferences in the determination of methylmercury in environmental and biological samples by ethylation-gas chromatographycold vapor atomic fluorescence spectrometry. Talanta 43(11):1883-1888.

16. Lin L, Chang, L, \& Jiang S (2008) Speciation analysis of mercury in cereals by liquid chromatography chemical vapor generation inductively coupled plasma-mass spectrometry. Journal of Agricultural and Food Chemistry 56(16):6868-6872.

17. Lin $Y$, Larssen $T$, Vogt RD, Feng $X(2010)$ Identification of fractions of mercury in water, soil and sediment from a typical $\mathrm{Hg}$ mining area in Wanshan, Guizhou province, China. Appl Geochem 25(1):60-68.

18. Li Q, Li T, Qiu G, Liu C (2020) Total mercury and methylmercury in the soil and vegetation of a riparian zone along a mercuryimpacted reservoir. Sci Total Environ 738:139794.

19. Li Y, Zhao J, Gao Y, Liu M, Xu Q, Li H, Li Y, Zheng L, Zhang Z, Gao Y (2017) Influence of sulfur on the accumulation of mercury in rice plant (Oryza sativa L.) growing in mercury contaminted soils. Chemo 182:293-300.

20. Lu R (2000) Chemical analysis method of agricultural soil. China Agriculture Science Press, Beijing, pp106-107.

21. MacDonald D, Ingersoll C, Berger T (2000) Development and evaluation of consensus-based sediment quality guidelines for freshwater ecosystems. Arch Environ Contam Toxicol 39:20-31.

22. Madejón P, Domínguez MT, Murillo JM (2012) Pasture composition in a trace element-contaminated area: the particular case of Fe and Cd for grazing horses. Environ Monit Assess 184(4):2031-2043.

23. Marrugo-Negrete J, Marrugo-Madrid S, Pinedo-Hernández J, Durango-Hernández J, Díez S (2016) Screening of native plant species for phytoremediation potential at a Hg-contaminated mining site. Sci Total Environ 542:809-816.

24. Meng B, Feng X, Qiu G, Liang P, Li P, Chen C, Shang L (2011) The process of methylmercury accumulation in rice (Oryza sativa L.). Environ Sci Technol 45:2711-2717.

25. MH (2017) Ministry of Health of the People's Republic of China, Maximum levels of contaminants in foods. GB 2762-2017, Beijing, China.

26. Peng H, Reid MS, Chris LeX (2015) Consumption of rice and fish in an electronic waste recyling area contributes significantly to total daily intake of mercury. J Environ Sci 12(38):83-86.

27. Qian X, Wu Y, Zhou H, Xu X, Xu Z, Shang L, Qiu G (2018) Total mercury and methylmercury accumulation in wild plants grown at wastelands composed of mine tailings: Insights into potential candidates for phytoremediation. Environ Pollu 239:757-767.

28. Qian X (2020) Tolerant plants and their accumulation mechanism of mercury in typical mercury mining areas. Dissertation, Guizhou University

29. Qiu G, Feng X, Meng B, Wang X (2012) Methylmercury in rice (Oryza sativa L.) grown from the Xunyang Hg mining area, Shanxi province, northwestern China. Pure Appl Chem 84:281-289.

30. Qiu G, Feng X, Wang S, Shang L (2005) Mercury and methylmercury in riparian soil, sediments mine-waste calcines, and moss from abandoned $\mathrm{Hg}$ mines in east Guizhou province, southwestern China. Appl Geochem 20(3):627-638.

31. Schwesig D, Krebs $O$ (2003) The role of ground vegetation in the uptake of mercury and methylmercury in a forest ecosystem. Plant Soi 253:445-455.

32. Shi J, Liang L, \& Jiang G (2005a) Simultaneous determination of methylmercury and ethylmercury in rice by capillary gas chromatography coupled on-line with atomic fluorescence spectrometry. Journal of AOAC International, 88(2):665-669.

33. Shi J, Liang L, Jiang G, \& Jin X (2005b). The speciation and bioavailability of mercury in sediments of Haihe River, China. Environment International, 31(3):357-365.

34. Tang Z, Fan F, Wang X, Shi X, Deng S, Wang D (2018) Mercury in rice (Oryza sativa L.) and rice-paddy soils under long-term fertilizer and organic amendment. Ecotox Environ Safe 150:116-122.

35. Tong Y, Zhang W, Hu D, Ou L, Hu X, Yang T, Wei W, Ju L, Wang X (2013) Behavior of mercury in an urban river and its accumulation in aquatic plants. Enviorn Earth Sci 68(4):1089-1097. 
36. USEPA (2001) Method 1630: Methylmercury in water by distillation, aqueous ethylation, purge and trap, and CVAFS. EPA-821-R01-020. Washington, DC.

37. Wang J, Feng X, Anderson CWN, Qiu G, Li P, Bao Z (2011) Ammonium thiosulphate enhanced phytoextraction from mercury contaminated soil-Results from a greenhouse study. J Hazard Mater 186(1):119-127.

38. Xing D, Li R, Cao X, Liu H (2010) Heavy metal tolerance feature of Buddleja davidii in the indigenous zinc smelting area. J Mount Agric Biol 29:226-230 (in Chinese).

39. Xu X, Meng B, Zhang C, Feng X, Gu C, Guo J, Bishop K, Xu Z, Zhang S, Qiu G (2017) The local impact of a coal-fired power plant on inorganic mercury and methyl-mercury distribution in rice (Oryza sativa L.). Environ Pollut 233:11-18.

40. Xu X, Gu C, Feng X, Qiu G, Shang L, Xu Z, Lu Q, Xiao D, Wang H, Lin Y, Larssen T (2019) Weir building:A potential cost-effective method for reducing mercury leaching from abandoned mining tailings. Sci. Total Environ.651:171-178.

41. Xu Z, Abeysinghe K, Xu X, Gu H, Liang L, Lu Q, Zhang Y, Zheng L, Wang W, Qiu G (2019) New insights into the chemical forms of extremely high methylmercury in songbird feathers from a contaminated site. Chemosphere 225:803-809.

42. Xu Z, Lu Q, Xu X, Feng X, Liang L, Liu L, Li C, Chen Z, Qiu G (2020) Multi-pathway mercury health risk assessment, categorization and prioritization in an abandoned mercury mining area: A pilot study for implementation of the Minamata Convention. Chemosphere 260:127582.

43. Yoon J, Cao X, Zhou Q, Ma L (2006) Accumulation of $\mathrm{Pb}, \mathrm{Cu}$, and $\mathrm{Zn}$ in native plants growing on a contaminated Florida site. Sci Total Environ 368(2-3): 456-464

44. Zhang H, Feng X, Larssen T, Shang L, Li P (2010) Bioaccumulation of methylmercury versus inorganic mercury in rice (Oryza sativa L.) grain. Environ Sci Technol 44(12):4499-4504.

45. Zhang H, Fu X, Lin C, Shang L, Zhang Y, Feng X, Lin C (2016) Monsoon-facilitated characteristics and transport of atmospheric mercury at a high-altitude background site in southwestern China. Atmos Chem Phys 16:13131-13148.

46. Zhao L, Qiu G, Anderson C, Meng B, Wang D, Shang L, Yan H, Feng X (2016) Mercury methylation in rice paddies and its possible controlling factors in the Hg mining area, Guizhou province, southwest China. Environ Pollut 215:1-9.

\section{Figures}




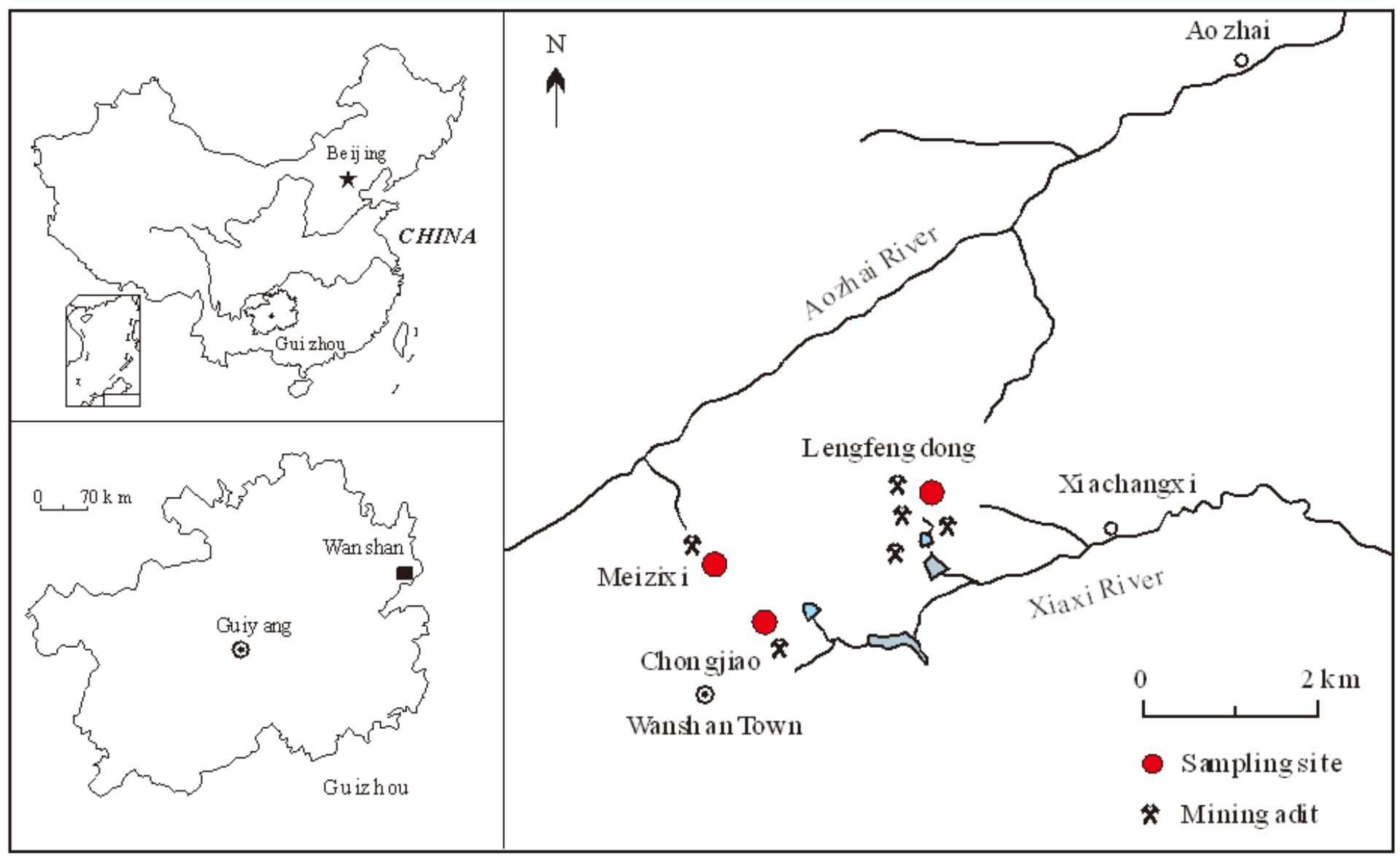

\section{Figure 1}

Study area and sampling sites Note: The designations employed and the presentation of the material on this map do not imply the expression of any opinion whatsoever on the part of Research Square concerning the legal status of any country, territory, city or area or of its authorities, or concerning the delimitation of its frontiers or boundaries. This map has been provided by the authors. 


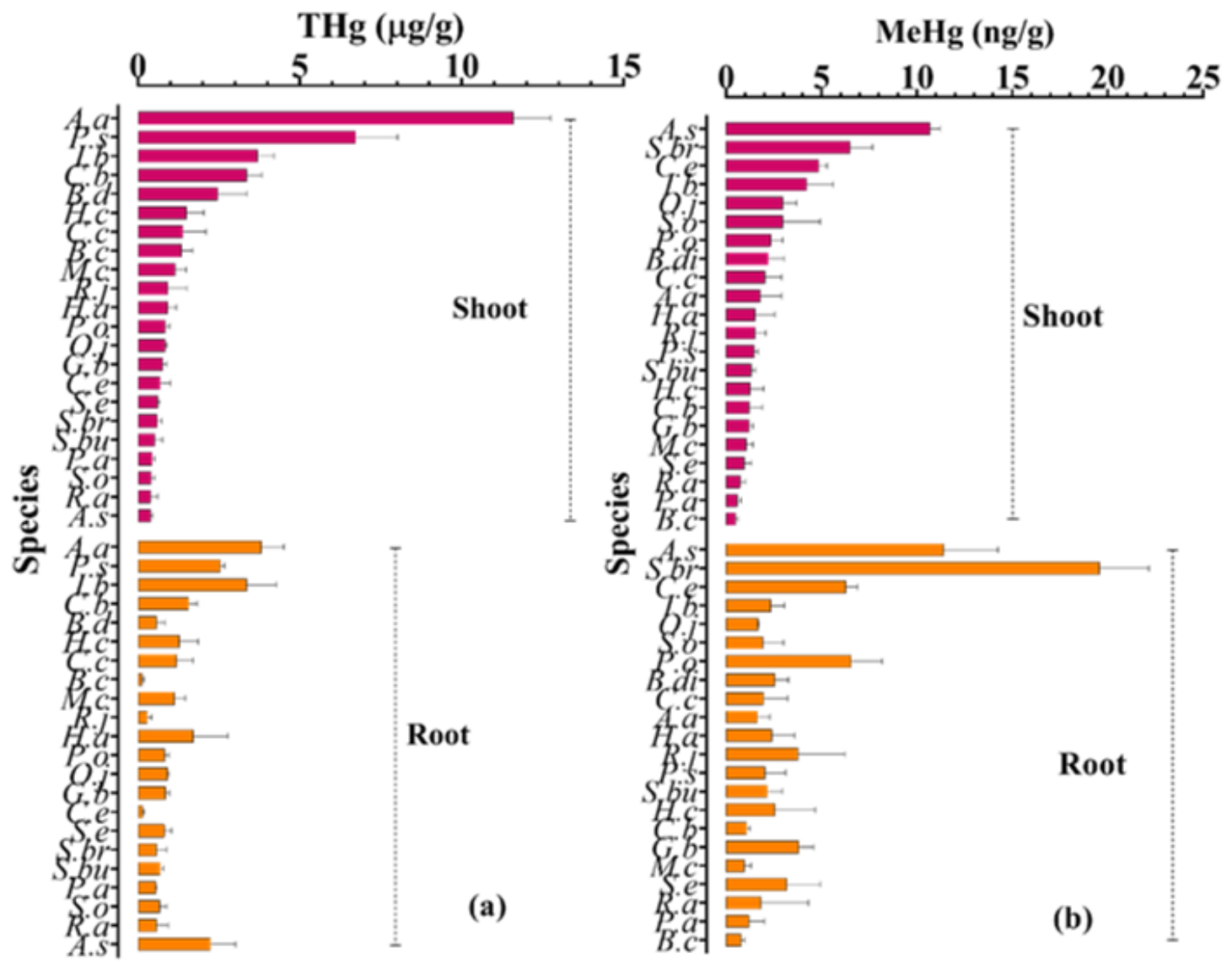

Figure 2

$\mathrm{THg}$ and $\mathrm{MeHg}$ in the roots and shoots of the forage plants 

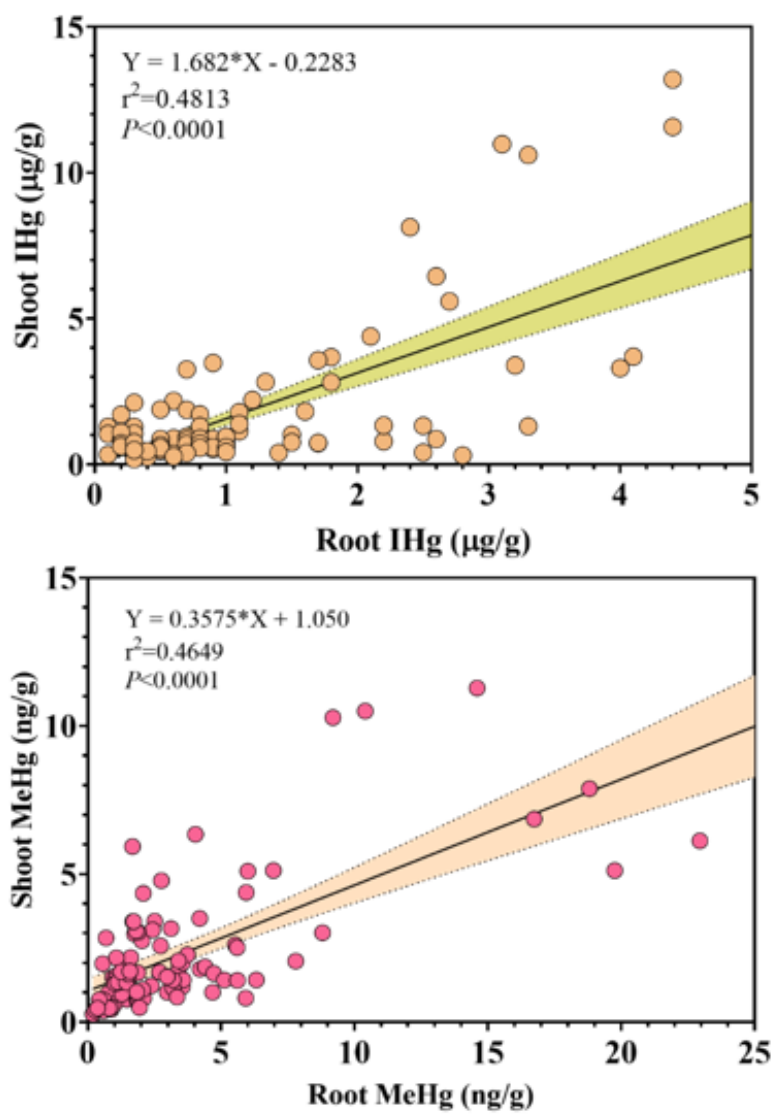

Figure 3

Correlation of $\mathrm{THg}$ and $\mathrm{MeHg}$ between the roots and shoots of the forage plants 

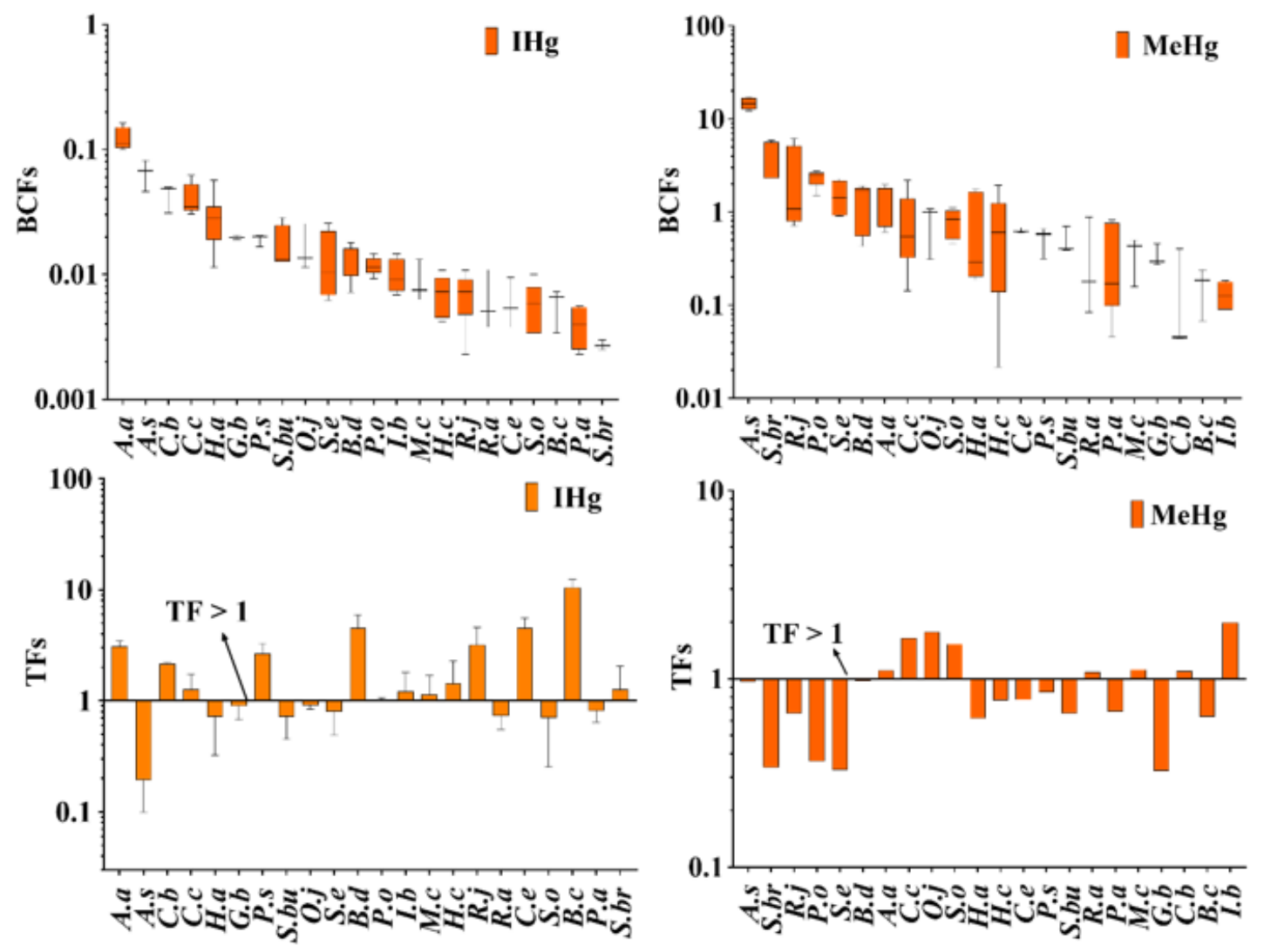

Figure 4

Distribution of the BCFs and TFs for $\mathrm{IHg}$ and $\mathrm{MeHg}$ in the forage plants 

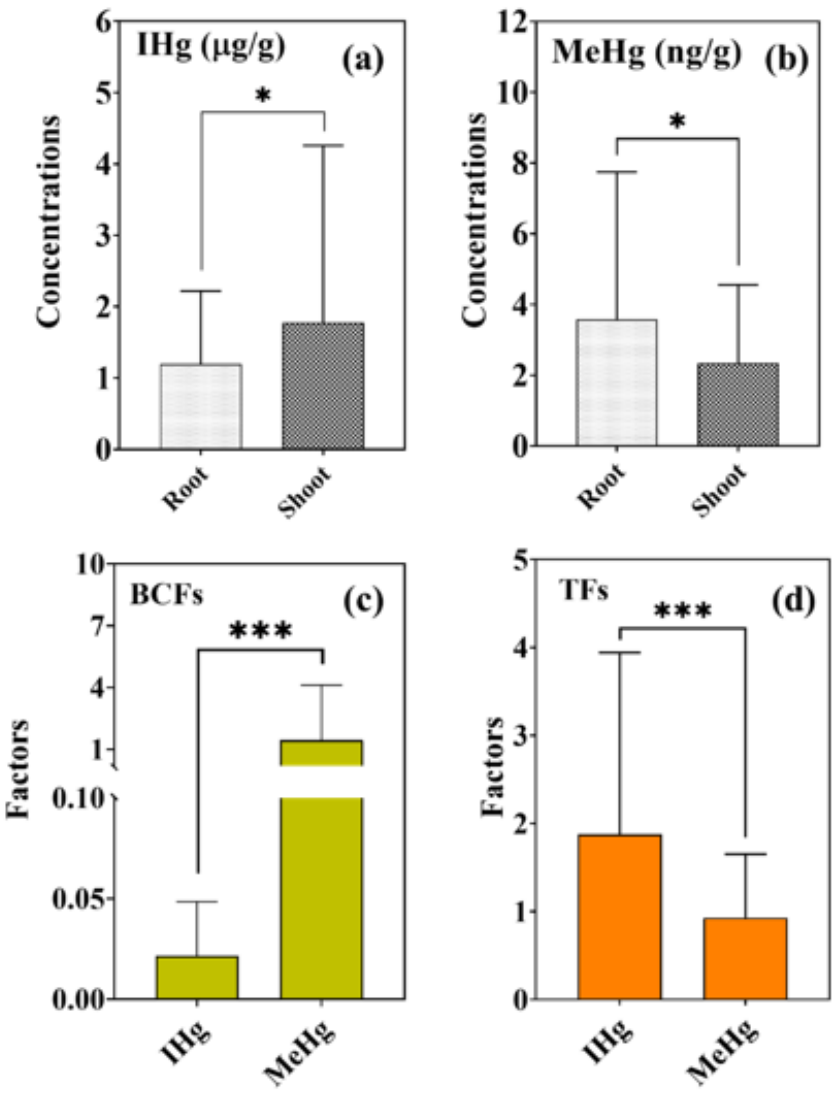

Figure 5

Differences in $\mathrm{IHg}, \mathrm{MeHg}, \mathrm{BCF} s$, and TFs between the roots and shoots of the forage plants $\left({ }^{*} \mathrm{P}<0.05,{ }^{*} * \star \mathrm{P}<0.0001\right)$ 


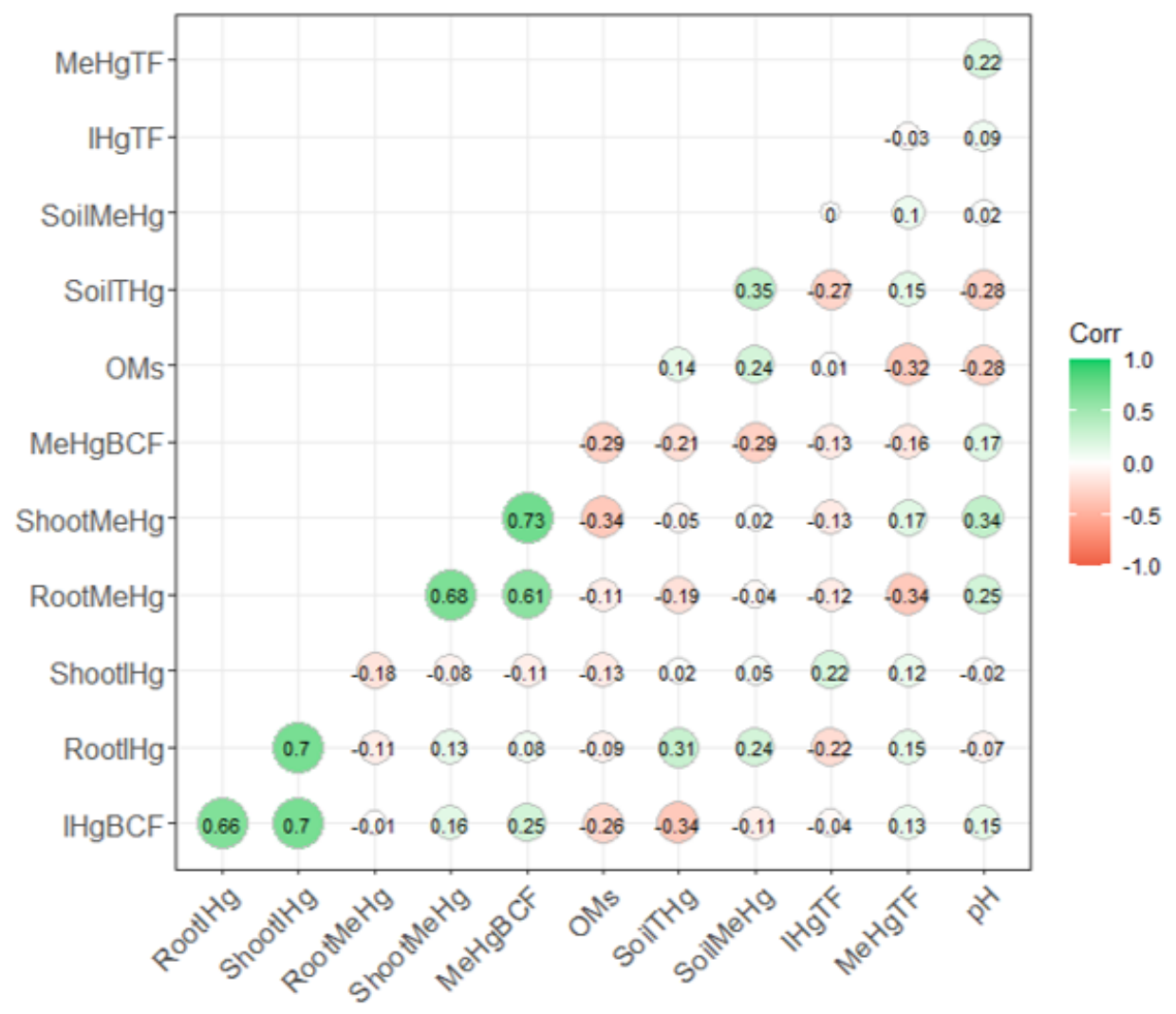

Figure 6

Pearson correlation analysis of the $\mathrm{THg}$ and $\mathrm{MeHg}$

\section{Supplementary Files}

This is a list of supplementary files associated with this preprint. Click to download.

- SupplementalMaterials.docx 